\title{
PVX-tolerant potato development using a nucleic acid-hydrolyzing recombinant antibody
}

\author{
J.-G. YANG ${ }^{1 *}$, K.-H. HWANG ${ }^{1,2 *}$, E.-J. KIL ${ }^{1}$, J. PARK ${ }^{1,3}$, S. CHO ${ }^{1}$, Y.-G. LEE ${ }^{4}$, C.-K. AUH ${ }^{5}$, Y. RHEE ${ }^{6 *}$, S. LEE ${ }^{1 *}$
}

\begin{abstract}
${ }^{1}$ Department of Genetic Engineering, Sungkyunkwan University, Suwon 16419, Korea; ${ }^{2}$ Research and Development Department, Gyeonggi-do Agricultural Research and Extension Services, Hwaseong 18388, Korea; ${ }^{3}$ Plant Quarantine Technology Center, Animal and Plant Quarantine Agency, Gimcheon 39660, Korea; ${ }^{4}$ Highland Agriculture Research Center, National Institute of Crop Science, Rural Development Administration, Pyeongchang 25342, Korea; ${ }^{5}$ Department of Biological Sciences, Mokpo National University, Muan 58554, Korea; ${ }^{6}$ Institute of Biotechnology and Bioengineering, Sungkyunkwan University, Suwon 16419, Korea
\end{abstract}

Received March 24, 2016; revised November 9, 2016; accepted January 12, 2017

\begin{abstract}
Summary. - 3D8 scFv, a catalytic recombinant antibody developed in the MRL mouse, exhibits nucleic acidhydrolyzing activity. Previous studies have demonstrated that tobacco plants harboring 3D8 scFv antibodies showed broad-spectrum resistance to infection by both DNA and RNA viruses. In this study, potatoes were transformed with the $3 \mathrm{D} 8 \mathrm{scFv}$ gene and screened by potato virus X (PVX) challenge. Starting with the T0 and T1 potato lines, PVX-tolerant T1 potatoes were identified in the field and characterized by ELISA and RT-PCR analysis. T2 potatoes were propagated for T3 generation and additional virus challenges in the field, and $44 \%$ of the 3D8 scFv T3 transgenic potatoes grown in GMO fields were found to be tolerant to PVX infection. Tubers from PVX-tolerant T3 lines were 60\% bigger and 24\% heavier, compared with tubers from PVX-susceptible transgenic lines and wild-type potatoes. Three-step virus challenge experiments and molecular characterization techniques were used for plants grown in growth chambers or fields to identify 3D8 scFv-transgenic, PVXtolerant potatoes. These studies also revealed that the viral tolerance enabled by 3D 8 scFv persisted during asexual propagation.
\end{abstract}

Keywords: potato virus X; 3D8 scFv; agrobacterium-mediated transformation; transgenic potato; PVX tolerance

\section{Introduction}

Potatoes (Solanum tuberosum L.) are the world's fourthlargest agronomical crop after maize, rice, and wheat. Approximately 330 million tons of potatoes are grown per annum, in more than 130 countries (Rakosy-Tican et al., 2007). Potato plants are easily infected by viruses, such as potato leaf roll virus (PLRV), potato virus X (PVX), and potato virus

${ }^{*}$ Co-corresponding authors. E-mail addresses: rhreepd@skku. edu, cell4u@skku.edu; phone: +82-31-290-7866. "These authors contributed equally to this work.

Abbreviations: $\mathrm{CP}=$ coat protein; $\mathrm{MS}=$ Murashige and Skoog; $\mathrm{PVX}=$ potato virus $\mathrm{X} ; \mathrm{PVY}=$ potato virus $\mathrm{Y} ; \mathrm{TYLCV}=$ tomato yellow leaf curl virus
Y (PVY) (Hull, 1984; Verchot-Lubicz et al., 2007), causing severe yield losses every year. Furthermore, the vegetative propagation of potatoes makes viral infections even more destructive: viruses persist in infected tubers and are then transmitted to propagated tuber clones, thus causing more severe secondary infections over several generations. Due to the lack of available virucides, approaches to control viral damage in potato plants have thus been limited to two main strategies: 1) the production of pathogen-free stocks in tissue cultures, and 2) the development of virus-resistant potato plants through genetic manipulation (Solomon-Blackburn and Barker, 2001a,b).

PVX is a plant pathogenic virus of the family Alphaflexiviridae and the order Tymovirales. It is the prototype species of the genus Potexvirus. PVX is found mainly in potatoes and is only transmitted mechanically. PVX causes mild or 
no symptoms in most potato varieties, but when plants are co-infected with PVX and PVY, synergy between these two viruses causes severe symptoms in potatoes. To protect potatoes against PVX infection, several genetic manipulation approaches with different genes have been implemented (Hemenway et al., 1988,1989).

Genetic manipulation strategies for the development of virus-resistant crops rely mainly on resistance genes derived from either the host plants or pathogens (Beachy, 1997; Goldbach et al., 2003; Runo, 2011). Pathogen-derived resistance consists of the transformation of plants with resistance genes derived from viral genomes, and involves either protein-mediated or RNA-mediated mechanisms (Prins et al., 2008).

The coat protein (CP) genes of PVX and PVY were introduced into a major commercial cultivar of potato, Russet Burbank, and transgenic plants that expressed both $\mathrm{CP}$ genes were found to be resistant to infection by PVX and PVY by mechanical inoculation. This engineered resistance experiment indicated that $\mathrm{CP}$ protection was effective against mixed infection by two different viruses (Lawson et al., 1990). In another study, transgenic tobacco plants harboring either the sense coat protein transcript $(\mathrm{CP}+$ sense) of PVX or the antisense coat protein transcript (CP-antisense) were protected against PVX infection. The extent of protection observed in $\mathrm{CP}+$ plants depended primarily upon the level of expression of the coat protein. Plants expressing antisense RNA were protected only at low inoculum concentrations (Hemenway et al., 1988). When mutations were introduced into the sequence encoding the GDD motif of the putative replicase component of PVX, all mutations tested rendered the viral genome completely noninfectious when inoculated into tobacco plants. These results suggest that viral resistance to a plant virus may be engineered by expression of dominant negative mutant forms of viral genes in transformed cells (Longstaff et al., 1993).

In addition to virus-mediated resistance, a host gene-mediated resistance for PVX was reported. Resistance to PVX is characterized by the gene product of a host resistance gene and a viral determinant. PVX strains showed typical 'genefor-gene' type resistance interactions in respect of the host $\mathrm{Nx}, \mathrm{Nb}$ and Rx genes (Baulcombe et al., 1995). The viral coat protein of PVX is known for the determinants of resistance mediated by the host $\mathrm{Nx}$ gene while the movement protein is the determinant of $\mathrm{Nb}$-mediated resistance. Virulence or avirulence by the interactions between the determinants of PVX and host factors was dependent on the different groups of PVX strains (Malcuit et al., 2000). Specially Rx mediated resistance against PVX infection was dependent on RanGAP2, which interacts with the Rx CC domain by disrupting either the intramolecular interaction or the interaction with RanGAP2 (Sacco et al., 2007; Tameling and Baulcombe, 2007). Based on the structural and functional analysis, a new model of CC-NB-LRR function was reported as the LRR and CC domains could co-regulate the signaling activity of the NB domain in a recognition-specific manner (Rairdan et al., 2008).

Genetically engineered resistance established using resistance genes can breakdown upon recombination between virus strains or mutations in resistant determinants of the viral genome. Two clones of PVX strains, PVX (UK3) and PVX (HB), have been constructed in plasmid vectors as infectious clones and the PVX (HB) clone was used to systemically infect tobacco and susceptible potato cultivars. However, the infectious clone of PVX (UK3) failed to infect the $R x$ plants or show a hypersensitive response of the $N x$ gene. Hybrid viral genomes between PVX (UK3) and PVX (HB) were constructed to elucidate the resistance breaking determinants of PVX (HB). Transcripts of hybrids were infectious on potato cultivars with either the $R x$ or $N x$ resistance genes. These results indicated that hybrid viruses generated with closely related strains or mutations in viral genomes may overcome the host resistance gene (Kavanagh et al., 1992). Similar experiments have also been performed with another PVX strain (DX), and showed different symptoms based on different host resistant genes, such as systemic top necrosis in presence of the potato hypersensitivity gene $N x$ and mosaics with gene $\mathrm{Nb}$ (Jones, 1982).

Each approach has its own advantages and disadvantages; however, the virus-resistant potatoes that have been engineered thus far have in general shown only narrow-spectrum resistance to their target viruses (Prins et al., 1996; van den Boogaart et al., 2001). To overcome these limitations, a novel approach was developed as an alternative to pathogen-derived resistance strategies for plant systems. This approach includes the expression of antibodies against viral proteins in the plant body (Boonrod et al., 2004; Tavladoraki et al., 1993). Although the antibody-mediated immune response is known to be unique to animals, the high affinity of some antibodies to their target antigens is sufficient to inhibit viral infection in plants. The essential goal of this technology is to generate a recombinant antibody in a host plant ("plantibody"); specifically, a single-chain variable fragment (scFv) consisting of the variable regions of the heavy $\left(\mathrm{V}_{\mathrm{H}}\right)$ and light $\left(\mathrm{V}_{\mathrm{L}}\right)$ chains of an immunoglobulin molecule, connected by a short linker peptide (Bird et al., 1988). The first successful demonstration of plantibody-mediated resistance was performed in tobacco plants (Nicotiana benthamiana) transformed with a gene encoding a functional scFv raised against the coat protein of artichoke mottled crinkle virus (Tavladoraki et al., 1993). Subsequently, varieties of transgenic plants with antibody-engineered resistances to citrus tristeza virus (Cervera et al., 2010), tomato yellow leaf curl virus (TYLCV) (Safarnejad et al., 2009), and PLRV (Nickel et al., 2008) were also developed. 
The "abzyme" originates from the terms "antibody" and "enzyme" (Tramontano et al., 1986). The catalytic antibodies called abzymes combined the characteristics of antibodies and enzymes with therapeutic effects. Over the 30 years, catalytic antibodies which hydrolyze DNA and RNA have been observed in the sera of patients with various autoimmune diseases such as systemic lupus erythematosus (SLE), multiple sclerosis, primary Sjogren's syndrome, Hashimoto thyroiditis, myasthenia gravis and rheumatoid arthritis (Dubrovskaya et al., 2003; Krasnorutskii et al., 2008). 3D8 scFv immunoglobulin molecules were first isolated from spleen cells of the autoimmune MRL-lpr/lpr mouse. These immunoglobulins enable the development of viral resistance via nucleic acid binding/hydrolyzing, without any sequence specificity for single-stranded or double-stranded DNA (Kwon et al., 2002). Moreover, 3D8 scFv molecules can indiscriminately inhibit infection by both animal and plant viruses, since their target is only recognized as a nucleic acid. HeLa cells expressing 3D8 scFv molecules exhibit strong antiviral activity against classical swine fever virus infection (Jun et al., 2010). Recently, these nucleic acid-hydrolyzing recombinant antibodies were also demonstrated to elicit virus resistance in tobacco plants (Lee et al., 2013a,b). Interestingly, we also obtained evidence that resistance to infection by a different virus species, geminivirus, can be induced in 3D8 scFvtransgenic tobacco plants (Nicotiana benthamiana).

In the current study, the 3D8 scFv gene was introduced into the potato genome for the first time, and the antiviral effects of $3 \mathrm{D} 8 \mathrm{scFv}$ on a potato virus were investigated in clonal progeny propagated through the tubers of potato transformants, with PVX challenges over three consecutive transgenic generations (T0 to T3). Our results show that PVX tolerance can be stably maintained through multiple 3D8 scFv-transgenic potato generations.

\section{Materials and Methods}

Plant material and growth conditions. Solanum tuberosum cv. Superior potatoes were used in this study. For transformations, plants were grown in vitro and maintained under a 16/8 h light/ dark regimen at 50\% humidity on Murashige and Skoog (MS) medium (Murashige and Skoog, 1962), supplemented with 2\% (w/v) sucrose and agar. Transgenic lines selected for biochemical analysis and virus challenge experiments were micropropagated from seed tubers in a growth chamber under a long-day conditions $(16 \mathrm{~h})$ at $25 \pm 2{ }^{\circ} \mathrm{C}$. The mass propagation and maintenance of transgenic potatoes was performed at the Highland Agriculture Research Center, National Institute of Crop Science, Korea.

Plasmid construction. The $3 \mathrm{D} 8 \mathrm{scFv}$ gene was derived from a hybridoma cell line, originating from an autoimmune-prone MRL-lpr/lpr mouse, which produces MAb 3D8 IgG (Kwon et al., 2002). 3D8 scFv consists of the VH (NCBI accession number
AAF79128) and VL (NCBI accession number AAF79129) genes with a $\left(\mathrm{Gly}_{4} \mathrm{Ser}\right)_{3}$ flexible linker inserted between the $\mathrm{V}_{\mathrm{H}}$ and $\mathrm{V}_{\mathrm{L}}$ sequences (VH-( $\left.\left.\mathrm{Gly}_{4} \mathrm{Ser}\right)_{3}-\mathrm{VL}\right)$. This gene was subcloned into pGEM ${ }^{\circ}$-T Easy (Promega, USA), as described in previous studies (Kim et al., 2006). From this construct, a DNA fragment encoding the 3D8 scFv molecule was amplified by PCR using primers 5'-TCTAGAATGGAGGTCCAGCTGCAGCA-3' and 5'-GAGCTCTTATATTTCCAGCTTGGTCCCCG-3'. The resultant PCR products were subcloned into GEM $^{\circ}$-T Easy, thereby generating pGEM-3D8 scFv. This construct was digested with SacI and SpeI, and the resultant fragment was subcloned into the binary vector pBI121 (BD Biosciences Clontech, USA, NCBI accession number AF485783), thereby generating pBI121-3D8scFv. This vector was then transformed into Agrobacterium tumefaciens LBA4404 (Fig. 1a).

Potato transformation. Transgenic plants were constructed using an Agrobacterium-mediated transformation method modified from the previously reported protocol (Beaujean et al., 1998). Potato leaf discs were prepared by cutting leaves from 4 weeks old potato plants in length of approximately $4-6 \mathrm{~cm}$. The A. tumefaciens strain LBA4404 harboring the plasmid pBI121-3D8scFv was incubated for $16 \mathrm{~h}$ with shaking at $28^{\circ} \mathrm{C}$ in $50 \mathrm{ml} \mathrm{YEP}$ broth medium containing antibiotics ( $100 \mu \mathrm{g} / \mathrm{l}$ rifampicin and $50 \mu \mathrm{g} / \mathrm{l} \mathrm{kanamycin})$. The culture medium was centrifuged and resuspended in two volumes of MS liquid medium (MS salts and vitamins MS, 3\% sucrose, $\mathrm{pH}$ 5.7). MS media containing Agrobacterium cells was poured onto Petri dishes containing potato leaf discs. After two to three days of primary culture on MS medium in vitro, sampled leaf explants were co-cultured with A. tumefaciens for the next three days. Cultures were maintained on selection medium containing $250 \mathrm{mg} / \mathrm{l}$ cefotaxime and $100 \mathrm{mg} / \mathrm{l}$ kanamycin. One month after culture initiation, the shoots had regenerated from calli and were transferred to hormone-free medium for rooting (Fig. $1 \mathrm{~b}$ left). Rooted potato plantlets were subjected to continuous selection and acclimatization for two months to obtain healthy transformants (Fig. 1b right).

Transcript analysis of transgenic plants by RT-PCR. Total RNA was isolated from transgenic plants, as previously described by Schwach et al. (2005). cDNA was synthesized from total RNA using a oligo $(\mathrm{dT})_{18}$ primer and M-MLV reverse transcriptase (Rexgene Biotech, Korea) and used as a template for PCR. Potato actin was used as an internal control. Amplifications were carried out in triplicates. Thermocycling conditions were as follows: $94^{\circ} \mathrm{C}$ for $30 \mathrm{~s}, 35 \mathrm{cycles}$ of $60^{\circ} \mathrm{C}$ for $30 \mathrm{~s}$ and $72^{\circ} \mathrm{C}$ for $1 \mathrm{~min}$, followed by a final extension at $72^{\circ} \mathrm{C}$ for $5 \mathrm{~min}$. The PVX diagnostic primer sets (forward and reverse) were: actin, 5'-GCTTCCCGATGGTCAAGTCA-3' and 5'-GGATTCCAGCTGCTTCCATTC-3'; PVX coat protein, 5'-CAGTCCACCTGCTAACTGG-3' and 5'-TRACAGCT GCATCTAGGCT-3'; and 3D8 scFv, 5'-CTGCAAGGCTTCT GGATACAC-3' and 5'-GTTTAGGAGACTGCCCTGGTT-3'. PCR products were visualized on a $1 \%$ agarose gel stained with $50 \mu \mathrm{g} / \mathrm{ml}$ ethidium bromide.

PVX challenge. PVX inoculation was performed on 4 weeks old transgenic potato plants. Homogenates of PVX-infected po- 
(a)

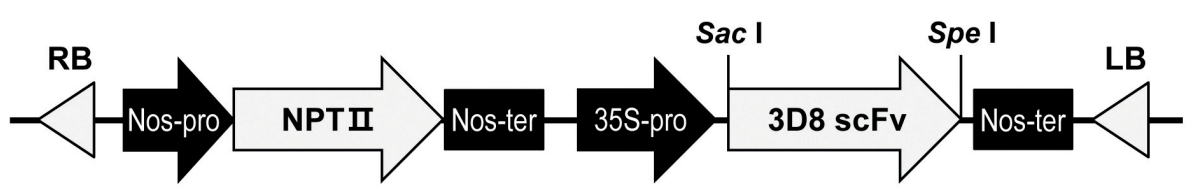

(b)
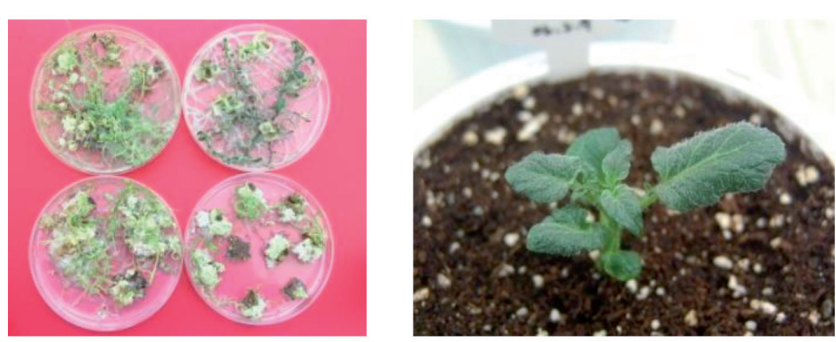

(c)

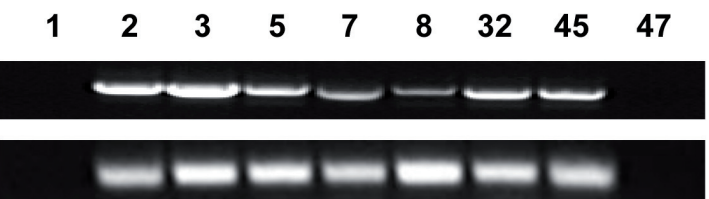

Fig. 1

Development of 3D8 scFv-transgenic potato plants

(a) Binary construct containing the T-DNA region and 3D8 scFv. The 3D8 scFv gene was subcloned into the binary vector, pBI121, with SacI/SpeI and subsequently introduced into Agrobacterium LBA4404. The region between the triangles (RB/LB: right/left border) represents the T-DNA fragment in the binary construct. Nos-pro, plant-recognizable promoter sequence derived from the nopaline synthase promoter of A. tumefaciens; NPT II, neomycin phosphotransferase II gene, whose product confers resistance to the antibiotic neomycin; Nos-ter, plant-recognizable terminator sequence derived from the nopaline synthase gene; 35S-pro, cauliflower mosaic virus-derived plant-recognizable promoter sequence; 3D8 scFv, 3D8 scFv DNA fragment. (b) Regeneration of 3D8 scFv-transformed potato leaf tissue in vitro. After cocultivation with A. tumefaciens, leaf explants were cultured on selection medium containing $250 \mathrm{mg} / \mathrm{l}$ cefotaxime and $100 \mathrm{mg} / \mathrm{l}$ kanamycin (left panel). Regenerated shoots were transferred to hormone-free MS medium for rooting. Finally, healthy potato plantlets were selected and grown in a pot (right panel). (c) Establishment of the T0 generation for 3D8 scFv potato transformants. A total of nine putative transgenic lines were obtained after acclimatization and analyzed to confirm the presence of the 3D8 scFv gene by RT-PCR. The NPT II gene was used as an internal control. Seven lines were selected as genuine transformants and designated as the T0 generation (lanes 2, 3, 5, 7, 8, 32, and 45). Lane 1 and 47 are negative controls - non-transformants.

tato leaves were used as the inoculum. Young leaves of the potato plants were lightly dusted with carborundum, and virus inoculum $(50 \mu \mathrm{l})$ was applied to the scratched leaves with a cotton swab. The inoculated plants were incubated at $22^{\circ} \mathrm{C}-25^{\circ} \mathrm{C}$ and were typically observed for 30 to 45 days (Sonoda et al., 2000). Symptom severity was scored using the external visible symptoms of PVX, based on developed leaves or shoot stunting. ELISAs were performed using shoots that had emerged from the inoculated potatoes. Three quantitative traits (length of major/minor axes, weight, and number) were evaluated for the tubers of PVX-inoculated transgenic and wild-type plants. All measurements were analyzed by Student's $t$-test using GraphPad Prism 5 (USA). A $P$-value of $\leq 0.05$ was considered statistically significant.

ELISA. Potato total protein extracts were prepared as previously described by Hemenway et al. (1988). A double-antibody sandwich ELISA kit (Agdia, USA) was used to detect the PVX coat protein (CP) in the extracts. A 1:200 dilution was generally used, both for coating plates with polyclonal PVX CP rabbit antiserum and for detecting PVX coat protein with alkaline phosphatase-conjugated antibody. One-way ANOVA was used to test for significant differences between the quantified amounts of PVX protein.

\section{Results}

\section{Genetic transformation}

A total of 205 calli were induced from the 542 leaf explants used for genetic transformation, and 45 plantlets with roots were regenerated from the 84 callus-derived shoots in the subsequent shooting and rooting steps. The average transformation efficiency was approximately 8.3\%, and a total of nine putative transgenic lines were produced after acclimatization. Of these, 7 transgenic lines were confirmed by RT-PCR analyzis to show the 3D8 scFv and NPT II genes and were designated as T0 generation (Fig. 1c). 
(a)

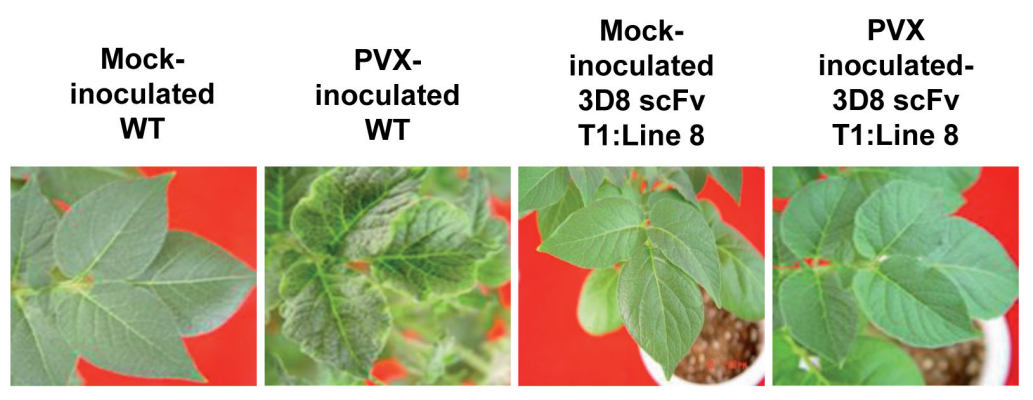

(b)

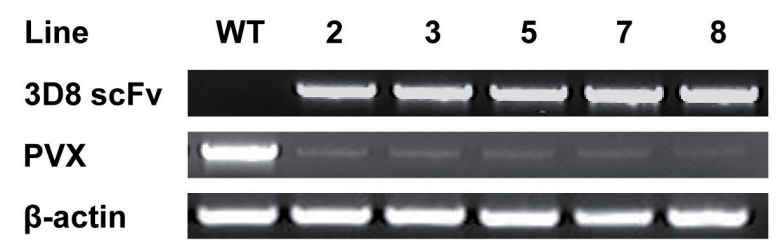

Fig. 2

Antiviral effects against PVX in the first 3D8 scFv-transgenic generation (T1)

(a) Progression of disease symptoms in a wild-type and a 3D8 scFv-T1 potato plant after PVX inoculation. T1 plants were grown from T0 generation tubers. To test the susceptibility to PVX, five 3D8 scFv-T1 lines and a wild-type line were inoculated with PVX. A T1 plant (line 8) was selected as a representative plant from the T1 generations tested. Mock-inoculated wild-type and transgenic plants were included as internal controls for PVX inoculation. WT, wild-type; 3D8 scFv T1:line 8, T1 clonal progeny of 3D8 scFv-transgenic potato line 8. (b) Transcript analysis of PVX-inoculated 3D8 scFv-T1 potato plants. PVX transcript detection by RT-PCR was used as a molecular indicator of virus susceptibility of the T1 plants tested in Fig. $2 \mathrm{a}$ at 4 weeks post PVX inoculation. Actin was used as an internal control.

\section{Viral resistance testing in the 3D8 scFv-T1 generation}

Tubers were harvested from each of the seven confirmed transgenic potato plants and grown in a growth chamber $\left(28^{\circ} \mathrm{C}\right.$, relative humidity $\left.68 \%\right)$ for $5-6$ weeks, thereby producing a T1 generation. Leaf tissues were mechanically inoculated with PVX to evaluate the accumulation of virus (infectivity) and the development of disease (symptom severity) 4 weeks post inoculation.

Strong symptoms of infection were observed in the PVXinoculated wild-type plants. These symptoms consisted of leaf deformities with dwarfism and curling, which are known to be typical of PVX infection (Fig. 2a). Five transgenic T1 lines were challenged with PVX. Four of the T1 lines tested $(3,5,7$, and 8$)$ showed no symptoms; transgenic line 8 is shown as a representative sample (Fig. 2a). For internal controls, a mock-inoculated wild-type line and a transgenic line (3D8 scFv T1:line 8) (Fig. 2a) were evaluated; these lines did not exhibit any symptoms of PVX infection. Interestingly, however, the T1:line 2 plant developed strong symptoms similar to those of the inoculated wild-type plant (data not shown). The viral infectivities and the development of disease symptoms in the first generation (T1) of 3D8 scFv-transgenic potato plants after PVX inoculation are shown in Table 1.

PVX infectivity was determined by detection of a PVX transcript by RT-PCR in selected T1 lines. This analysis revealed, based on the presence of the PVX transcript, that all five $\mathrm{T} 1$ lines $(2,3,5,7$, and 8$)$ were infected by PVX (Fig. 2b). Collectively, these results strongly suggest that PVX tolerance was acquired in the first generation of four of the $3 \mathrm{D} 8 \mathrm{scFv}$-transgenic potato lines (T2 lines $3,5,7$, and 8 ).

\section{Viral resistance testing in the $3 D 8 s c F v$-T2 generation}

Tubers of the five $\mathrm{T} 1$ lines were planted in fields to obtain a second generation (T2) of 3D8 scFv-transgenic potato plants. The overall patterns of plant growth were similar in all T2 clonal progeny tested, although a slight difference in the vegetative growth phase was observed between $\mathrm{T} 2$ lines $3,5,7$, and 8 compared with line 2 .

Three quantitative traits (size, weight, and number of tubers) of the T2 clonal progeny were also evaluated. The average dimensions of the tubers from the wild-type plants were $6.8 \mathrm{~cm}$ and $4.2 \mathrm{~cm}$ on the major and minor axes, respectively, whereas the tubers from T2 potato plants had average dimensions of $5.95 \mathrm{~cm}$ and $4.49 \mathrm{~cm}$, respectively. The average tuber weights were $80.74 \mathrm{~g}$ and $88.30 \mathrm{~g}$ for the wild-type and T2 potato plants, respectively. Only a slight difference in the average tuber production was observed between the wild-type and T2 potato plants ( 8 tubers for the wild-type and 7 for the T2 plants) (Table 2). 
Table 1. Viral infectivity and manifestation of disease symptoms in the first generation (T1) of 3D8 scFv-transgenic potato plants after PVX inoculation

\begin{tabular}{lccc}
\hline & \multicolumn{2}{c}{ T1 potatoes } \\
\cline { 3 - 4 } & & Infectivity (\%) & Symptom severity \\
\hline WT & $10 / 10(100 \%)$ & + \\
\hline \multirow{2}{*}{ TD8 scFv line } & $1 / 1(100 \%)$ & + \\
& T1-5 & $0 / 1(0 \%)$ & - \\
& T1-3 & $0 / 1(0 \%)$ & - \\
& T1-8 & $0 / 1(0 \%)$ & - \\
\hline
\end{tabular}

Percentage of infectivity was calculated as the number of plants exhibiting symptoms of disease out of the total number of inoculated plants 2 weeks post PVX inoculation. Symptom severity indicates the extent to which symptoms of PVX infection developed in the infected plants. $(+)=$ symptoms were observed; $(-)=$ no symptoms were observed.

Collectively, these results indicate that the growth of T1 and T2 3D8 scFv-transgenic potato plants was not affected by the transgene, at least in the transgenic lines selected for this test. The above-ground growth and tuber formation rates of the T2 line 8-derived clonal progeny (8-33) represents the $\mathrm{T} 2$ generation.

For the viral resistance test, seven potato plants from four T2 lines $(3,5,7$, and 8$)$ were inoculated with PVX, and RT-PCR was used to detect viral RNA 4 weeks post inoculation. PVX transcripts were detected in all transgenic plants tested, indicating that all T2 clonal progeny had been infected with PVX (Fig. 3). However, the infected potato plants showed no disease symptoms. Furthermore, no differences were observed between these infected plants and the non-inoculated wild-type plants in terms of above-ground growth and tuber formation (data not shown). The T2:line 2 clonal progeny $(2-15,18)$ showed the same response to PVX challenge as the T1 generation of this line; that is, severe symptoms of viral infection developed and the PVX transcript was readily detected after PVX inoculation.

\section{Viral resistance testing in the $3 D 8 s c F v$-T3 generation}

T3 clonal progeny were generated from field-grown tubers from four T2 lines (2, 3, 5, and 8) selected from among the five potato lines tested in the second transgenic generation, and another set of PVX inoculations was carried out on these clonal progeny to monitor PVX tolerance in the third transgenic generation.

Disease symptoms were not consistently observed in the PVX-infected T3 clonal progeny derived from transgenic lines 3,5 , and 8 . In other words, virus tolerance was consistently present when these transgenic lines advanced to the T3 generation (data not shown). As a representative example, a PVX-infected line 8-derived T3 clonal plant (T3:8-33) had healthy leaves, similar to those of an uninfected wild-type plant (data not shown) and more expended leaves to those of an uninfected wild-type plant, and the tubers of the T3:8-33 plant were approximately $60 \%$ bigger and $24 \%$ heavier than those of the wild-type plant (Fig. 4a). On the other hand, two of the line 2-derived clones (2-15-3 and 2-18-3) were highly infected and manifested strong symptoms in the T3 generation (data not shown).

RT-PCR analysis showed that the PVX gene was detectable in all T3 clonal progeny of the tested lines $(2,3,5$, and

Table 2. Evaluation of three quantitative traits (size, weight, and number) in T2 clonal progeny tubers of 3D8 scFv-transgenic potato plants

\begin{tabular}{|c|c|c|c|c|c|c|}
\hline & & \multirow{2}{*}{$\begin{array}{c}\text { Total No. of } \\
\text { harvested } \\
\text { potato plants }\end{array}$} & \multirow{2}{*}{$\begin{array}{c}\text { Average No. of } \\
\text { tubers/plant }\end{array}$} & \multicolumn{2}{|c|}{ Average length $(\mathrm{cm})$ of tubers/plant } & \multirow{2}{*}{$\begin{array}{c}\text { Average weight (g) } \\
\text { of tubers/plant }\end{array}$} \\
\hline & & & & Major axis & Minor axis & \\
\hline WT & Total & 20 & $8.00 \pm 1.50$ & $6.80 \pm 4.10$ & $4.20 \pm 2.30$ & $80.74 \pm 2.00$ \\
\hline \multirow[t]{10}{*}{$3 \mathrm{D} 8 \mathrm{scFv}$} & Total line & 190 & $6.62 \pm 0.97$ & $5.95 \pm 1.14$ & $4.49 \pm 0.92$ & $88.30 \pm 5.52$ \\
\hline & $2-15$ & 23 & 5.9 & 3.8 & 3.0 & 79 \\
\hline & $2-18$ & 21 & 7.8 & 7.3 & 5.9 & 89 \\
\hline & $3-20$ & 16 & 6.7 & 4.9 & 3.7 & 81 \\
\hline & $5-35$ & 22 & 5.3 & 6.4 & 4 & 93 \\
\hline & $5-45$ & 13 & 7.3 & 4.9 & 3.9 & 85 \\
\hline & $7-36$ & 17 & 7.5 & 6.3 & 5.1 & 89 \\
\hline & $7-43$ & 20 & 5.1 & 7.2 & 5.5 & 92 \\
\hline & $8-21$ & 17 & 6.1 & 5.5 & 3.9 & 86 \\
\hline & $8-33$ & 22 & 7.5 & 6.3 & 4.6 & 93 \\
\hline
\end{tabular}

Data were analyzed with Student's $t$-test, using GraphPad Prism 5. A P-value of $\leq 0.05$ was considered statistically significant. 


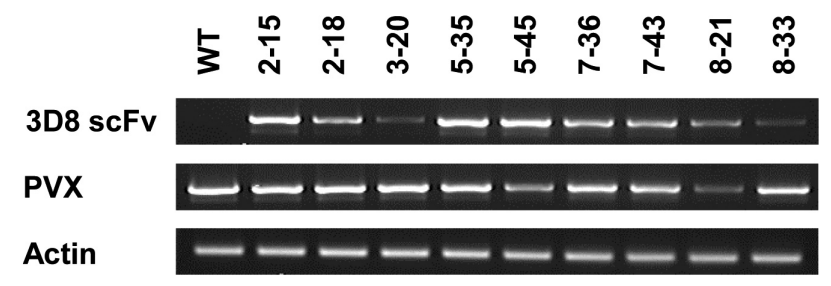

Fig. 3

Antiviral effects against PVX in the second 3D8 scFv-transgenic generation (T2)

Transcript analysis of PVX-inoculated 3D8 scFv-T2 potato plants. RT-PCR was used to detect the presence of the PVX transcript in nine subclonal potato plants from five transgenic lines in the T2 generation $(2,3,5,7$, and 8$)$ 4 weeks post-PVX inoculation. Actin was used as an internal control. Subclones are designated as follows: first number, transgenic T1 line; second number, $\mathrm{T} 2$ subclones from the transgenic $\mathrm{T} 1$ line.

(a)

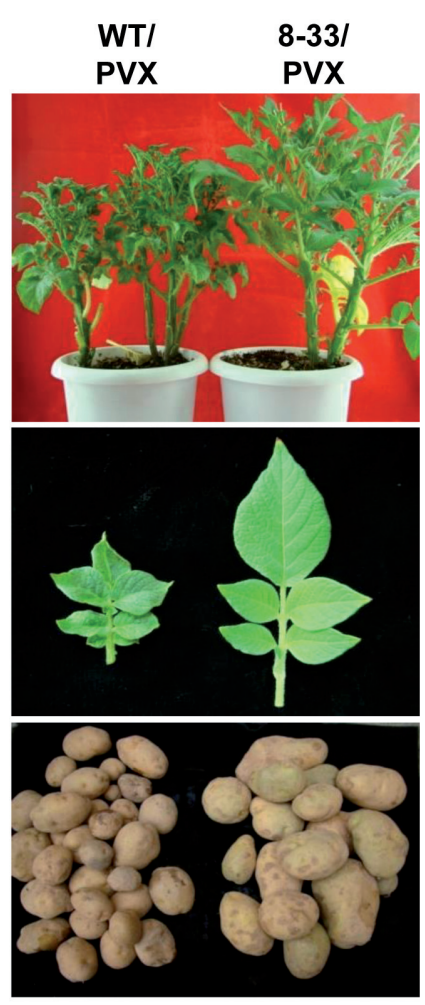

(c) (b)

8). Morphological observations and molecular data indicated that the PVX tolerance developed in the T2 generation was maintained in T3 clonal progeny of lines 3 and 5 of 3D8 scFv-transgenic potatoes (Fig. 4b).

It was particularly interesting that the line 8-21-derived T3 clonal progeny exhibited interclonal variation in their acquired PVX tolerance; the PVX gene was detected in two transgenic 8-21-derived T3 clonal progeny (8-21-1 and 8-21-5) even though 3D8 scFv was relatively highly expressed in both lines. For T3 lines 2-15-3 and 2-18-3, the results were consistent with those of the 8-21 transgenic lines, in that PVX transcripts were clearly detected in the plants regardless the different degree of $3 \mathrm{D} 8 \mathrm{scFv}$ transcription level.

In addition, ELISA was also conducted to confirm the presence of infection on the protein level in selected T3
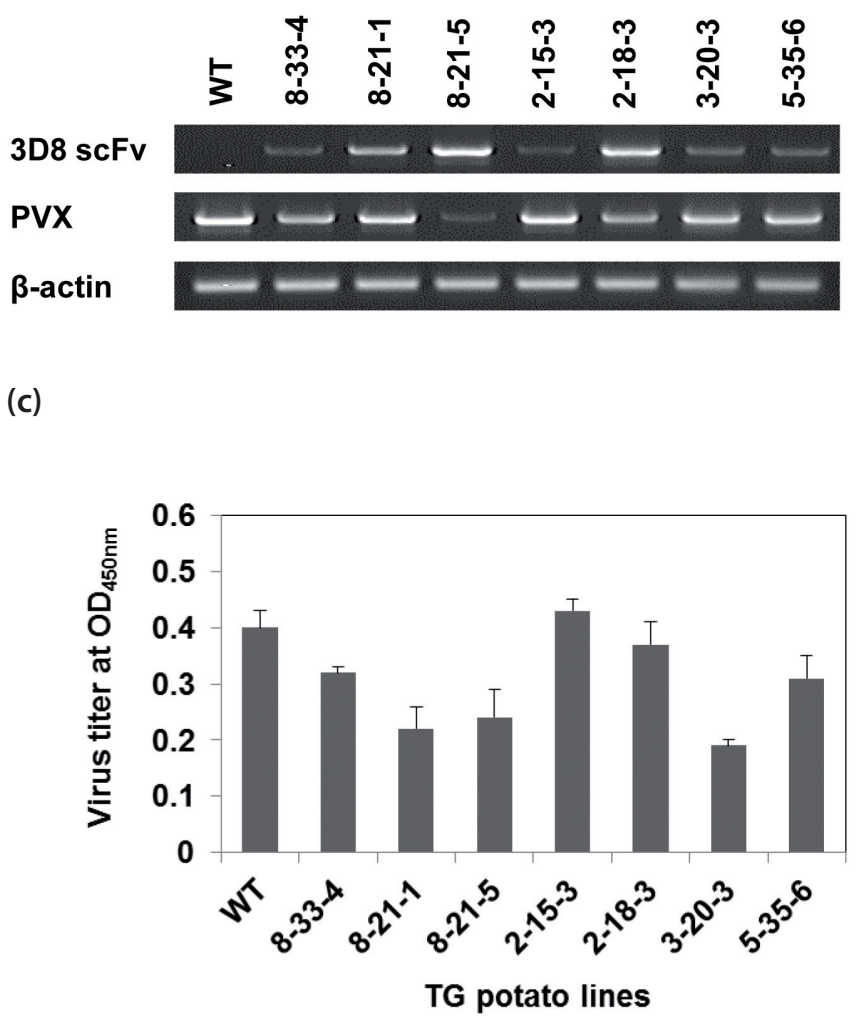

Fig. 4

Antiviral effects against PVX in the third 3D8 scFv-transgenic generation (T3)

(a) Growth of 3D8 scFv-T3 potato plants after PVX inoculation. T2 tuber-derived potato plants (T3 generation) were evaluated based on the severity of their disease symptoms and tuber formation to evaluate yield performance after PVX inoculation. A transgenic line 8-derived T2 subclone (T2:8-33) and a wild-type (WT) plant are shown as representative samples. (b) Transcript analysis of PVX-inoculated 3D8 scFv-T2 potato plants. The presence of PVX RNA was analyzed by RT-PCR in eight subclonal potato plants from the T3 clonal progeny of four transgenic lines $(2,3,5$, and 8$)$ at 4 weeks post-PVX inoculation. Actin was used as an internal control. Subclones are designated as follows: first number, transgenic T1 line; middle number, T2 subclone from the transgenic T1 line; last number, T3 clonal progeny from subclones tested in the T2 generation. (c) Detection of PVX accumulation by ELISA. The extent of PVX infection after PVX inoculation was assessed by ELISA for the selected T3 clonal progeny. The ELISA detected the PVX coat protein $(\mathrm{CP})$ in total transgenic potato extracts. X-axis, 3D8 scFv-transgenic potato lines tested; $\mathrm{Y}$-axis, virus concentration (virus titer) at $\mathrm{OD} 450 \mathrm{~nm}$. A $P$-value $<0.05$, indicating a statistically significant difference, is marked with an asterisk. 
clonal progeny after PVX inoculation. In general, viral protein was detected in all clonal progeny tested. In particular, the amount of viral protein detected, was nearly equal to or higher than that in the infected wild-type plant in the line 2-derived clones (2-15-3 and 2-18-3) (Fig. 4c).

\section{Discussion}

In agriculture, plant breeding has proven to be indispensable for the development of new cultivars with valuable genetic traits. However, classical breeding is based upon laborious and time-consuming genetic crosses. This process is even more intricate if the target crop species has complex genetics and reproductive organs. Furthermore, each step involves the mass migration and recombination of chromosomes during meiosis, resulting in the acquisition of novel desired traits in addition to unwanted ones, which entails an inevitable loss of desirable features. These major drawbacks of the classical breeding process can potentially be overcome through the use of genetic transformation techniques. However, successful transformation-mediated plant breeding requires stable transgene transmission over generations of the transformed plant species.

In this study, we aimed to devise a strategy for protecting crops against severe PVX infection. To do so, we introduced the 3D8 scFv gene into the potato genome to develop a PVXresistant potato cultivar and monitored the stability of the transgene in tuber-propagated transgenic potato generations from T0 to T3. Transgene genetics were simplified in this study by the clonal propagation of transformed potato plants via tuber formation. Direct transmission of the 3D8 $\mathrm{scFv}$ gene, with no genetic recombination or other genetic complexities, was assumed in all of the transgenic clonal progeny.

As demonstrated in our previous work, 3D8 scFv exhibits nucleic acid-hydrolyzing activity (Kim et al., 2006), and can digest any nucleic acid from either plant or animal viruses in a sequence-nonspecific manner (Jun et al., 2010). These characteristics may have practical applications in economically important crop plants. Among the many strategies for genetically-induced resistance against virus infections, 3D8 $\mathrm{scFv}$ is potentially more advantageous to crops in terms of viral resistance compared with other viral resistance approaches.

In our previous researches, 3D8 scFv was shown to exhibit antiviral effects against various plant (beet curly top virus, beet severe curly top virus, pepper mild mottle virus, tobacco mild green mosaic virus, tomato mosaic virus, tobacco mosaic virus and cucumber mosaic virus) and animal (pseudorabies virus, herpes simplex virus, classical swine fever virus, murine norovirus, influenza virus $\mathrm{H} 1 \mathrm{~N} 1, \mathrm{H} 9 \mathrm{~N} 2$ ) viruses (Cho et al., 2015; Hoang et al., 2015; Jun et al., 2010;
Kim et al., 2012; Lee et al., 2013a,b; 2014) at low 3D8 scFv protein concentrations. In the transgenic cells or mouse system, 3D8 scFv could only be detected by ELISA, but not by Western blot analysis of protein lysates (Jun et al., 2010; Lee et al., 2014). In previous study, the stability of cytosolicly expressed 3D8 scFv on plant development was confirmed by intrinsic nuclease activity of 3D8 scFv proteins (Lee et al., 2013a). When the stable transformants were established, they did not show significant difference observed in wt plants vs. transgenic plants. 3D8 scFv expression in fully developed transgenic plants could be hardly detected by western blot analysis even though they showed the complete resistance against virus infection. This was also observed on transgenic animal cell lines and mouse system (Lee et al., 2014). Taken together, we hypothesized that expression of low levels of 3D8 scFv could be good enough to protect against virus infection with no harmful effects on potato development.

The $3 \mathrm{D} 8 \mathrm{scFv}$ transgene was shown to be constitutively expressed in the selected T0 potato plants. However, among these transformants, transgenic line 2 was of particular interest due to its transgene effect. This plant, which was validated as transgenic, showed symptoms of infection and accumulated a level of virus similar to that in the PVXinfected wild-type plant after PVX inoculation, even though this transgenic plant harbored the 3D8 scFv gene. Moreover, this observed transgene abnormality in line 2 persisted in its clonal progeny throughout all generations examined (T1 to T3). The mechanism of this effect remains unclear. However, we consider the most likely explanation to be that the 3D8 $\mathrm{scFv}$ gene product had unidentified problems at the level of translation. It is quite possible that the final protein product of the 3D8 scFv gene underwent abnormal post-translational modification, or adopted a misfolded conformation. In such cases, an active nuclease would not have been formed by the defective 3D8 scFv protein, even though the gene was successfully expressed in the transgenic plant.

Another interesting observation was that viral tolerance was established as the generations advanced. Pathological and molecular data indicated that PVX tolerance was acquired in the T1 generation and persisted over in next generations of the transgenic clonal progeny. It would be informative to determine which factor(s) induced viral tolerance in later transgenic generations. The factor(s) involved may be either intrinsic (genetic) or extrinsic (environmentrelated) and may function to ensure optimal stability for plant survival. The most plausible explanation for the viral tolerance observed in this study may be viral-directed silencing suppression, as has been shown for TYLCV. The silencing of two partial TYLCV (C2 and C4) genes has been shown to interfere with the ability of the virus to counteract suppression of the virus by the host plant genes, thus engendering resistance or tolerance in tomato plants (Peretz et al., 2011). It is likely that PVX genes act through mechanisms similar 
to those of the TYLCV genes to generate viral tolerance to the 3D8 scFv gene, even though the precise factor(s)/ mechanism(s) involved in this process have not yet been identified in potato plants. If this is the case, the detection of the PVX gene in PVX-inoculated 3D8 scFv-transgenic potato clonal progeny strongly indicates that PVX gene suppression may occur at the post-transcriptional gene silencing level.

Couple of transgenic lines showed the correlation between tolerance against PVX infection and 3D8 scFv expression levels but in other lines, there was no correlation between them. In our previous works, (Lee et al., 2013a,b), we also observed similar observation. This might be caused by the catalytic activity of 3D8 scFv. The intrinsic catalytic activity of 3D8 $\mathrm{scFv}$ in transgenic lines may affect the difference between the transcriptional level of 3D8 scFv mRNA and the translational level of 3D8 scFv. In this case, we now understand that RTPCR data are not good enough to explain this correlation between resistance/tolerance against virus infection and 3D8 $\mathrm{scFv}$ expression levels. To prove this correlation, we need to have highly sensitive and specific anti-3D8 scFv antibody for quantifying $3 \mathrm{D} 8 \mathrm{scFv}$ proteins in each line.

Two of the T3 clones from transgenic line 8-21 (8-21-1, $5)$ showed variations in viral tolerance. The precise cause of this variation is unknown; however, clonal uniformity may be difficult to maintain in a fluctuating environmental milieu. One possibility is that unidentified environmental stressors may have caused genomic stress, thereby affecting the genomes of the transgenic potatoes in the field. This fine-tuning process may randomly affect $3 \mathrm{D} 8 \mathrm{scFv}$ transgene regulation in field-grown $\mathrm{T} 3$ clonal progeny, thus resulting in interclonal variation in PVX tolerance.

Acknowledgements. This study was supported by a grant from the Golden Seed Project (No. 213001-04-1-SB630) from the Ministry of Agriculture, Food and Rural Affairs.

\section{References}

Baulcombe D, Köhm B, Goulden M, Santa Cruz S, Forsyth A, Chapman S, Kavanagh T (1995): A" Gene for Gene" Interaction and Potato Virus X. World Scientific, pp. 333-351.

Beachy R (1997): Mechanisms and applications of pathogenderived resistance in transgenic plants. Curr. Opin. Biotechnol. 8, 215-220. https://doi.org/10.1016/S09581669(97)80105-X

Beaujean A, Sangwan R, Lecardonnel A, Sangwan-Norreel B (1998): Agrobacterium-mediated transformation of three economically important potato cultivars using sliced internodal explants: an efficient protocol of transformation. J. Exp. Bot. 49, 1589-1595. https://doi.org/10.1093/ $\mathrm{jxb} / 49.326 .1589$

Bird RE, Hardman KD, Jacobson JW, Johnson S, Kaufman BM, Lee SM, Lee T, Pope SH, Riordan GS, Whitlow, M (1988):
Single-chain antigen-binding proteins. Science 242, 423. https://doi.org/10.1126/science.3140379

Boonrod KJ, Galetzka D, Nagy PD, Conrad U, Krczal, G (2004): Single-chain antibodies against a plant viral RNA-dependent RNA polymerase confer virus resistance. Nat. Biotechnol. 22, 856-862. https://doi.org/10.1038/nbt983

Cervera M, Esteban O, Gil M, Gorris MT, Martínez MC, Pe-a L, Cambra, M (2010): Transgenic expression in citrus of single-chain antibody fragments specific to Citrus tristeza virus confers virus resistance. Transgenic Res. 19, 1001-1015. https://doi.org/10.1007/s11248-010-9378-5

Cho S, Youn HN, Hoang PM, Cho S, Kim KE, Kil EJ, Lee G, Cho MJ, Hong J, Byun SJ, Song CS, Lee,S (2015): Preventive activity against influenza (H1N1) virus by intranasally delivered RNA-hydrolyzing antibody in respiratory epithelial cells of mice. Viruses 7, 5133-5144. https://doi. org/10.3390/v7092863

Dubrovskaya VV, Andryushkova AS, Kuznetsova IA, Toporkova LB, Buneva VN, Orlovskaya IA, Nevinsky GA (2003): DNAhydrolyzing antibodies from sera of autoimmune-prone MRL/MpJ-lpr mice. Biochem.-Moscow 68, 1081-1088. https://doi.org/10.1023/A:1026350426842

Goldbach R, Bucher E, Prins M (2003): Resistance mechanisms to plant viruses: an overview. Virus Res. 92, 207-212. https:// doi.org/10.1016/S0168-1702(02)00353-2

Hemenway C, Fang R-X, Kaniewski,WK, Chua N-H, Tumer NE (1988): Analysis of the mechanism of protection in transgenic plants expressing the potato virus $\mathrm{X}$ coat protein or its antisense RNA. EMBO J. 7, 1273.

Hoang PM, Cho S, Kim KE, Byun SJ, Lee TK, Lee S (2015): Development of Lactobacillus paracasei harboring nucleic acid-hydrolyzing 3D8 scFv as a preventive probiotic against murine norovirus infection. Appl. Microbiol. Biotechnol. 99, 2793-803. https://doi.org/10.1007/ s00253-014-6257-7

Hoekema A, Huisman MJ, Molendijk L, van den Elzen PJ, Cornelissen BJ (1989): The genetic engineering of two commercial potato cultivars for resistance to potato virus X. Nat. Biotechnol. 7, 273-278. https://doi.org/10.1038/ nbt0389-273

Hull R (1984): Rapid diagnosis of plant virus infections by spot hybridization. Trends Biotechnol. 2, 88-91. https://doi. org/10.1016/S0167-7799(84)80003-7

Jones R (1982): Breakdown of potato virus X resistance gene Nx: selection of a group four strain from strain group three. Plant Pathol. 31, 325-331. https://doi.org/10.1111/j.13653059.1982.tb01285.x

Jun HR, Pham CD, Lim SI, Lee SC, Kim YS, Park S, Kwon MH (2010): An RNA-hydrolyzing recombinant antibody exhibits an antiviral activity against classical swine fever virus. Biochem. Biophys. Res. Commun. 395, 484-489. https://doi.org/10.1016/j.bbrc.2010.04.032

Kavanagh T, Goulden M, Santa Cruz S, Chapman S, Barker I, Baulcombe D (1992): Molecular analysis of a resistancebreaking strain of potato virus X. Virology 189, 609-617. https://doi.org/10.1016/0042-6822(92)90584-C

Kim A, Lee JY, Byun SJ, Kwon MH, Kim YS (2012): Viral genome RNA degradation by sequence-selective, nucleic-acid 
hydrolyzing antibody inhibits the replication of influenza H9N2 virus without significant cytotoxicity to host cells. Antiviral Res. 94, 157-67. https://doi.org/10.1016/j. antiviral.2012.03.007

Kim YR, Kim JS, Lee SH, Lee WR, Sohn JN, Chung YC, Shim HK, Lee SC, Kwon MH, Kim YS (2006): Heavy and light chain variable single domains of an anti-DNA binding antibody hydrolyze both double-and single-stranded DNAs without sequence specificity. J. Biol. Chem. 281, 15287-15295. https://doi.org/10.1074/jbc.M600937200

Krasnorutskii MA, Buneva VN, Nevinsky GA (2008): Antibodies against RNA hydrolyze RNA and DNA. J. Mol. Recognit. 21, 338-347. https://doi.org/10.1002/jmr.906

Kwon MH, Lee MS, Kim KH, Park S, Shin HJ, Jang YJ, Kim HI (2002): Production and characterization of an antiidiotypic single chain Fv that recognizes an anti-DNA antibody. Immunol. Invest. 31, 205-218. https://doi. org/10.1081/IMM-120016241

Lawson C, Kaniewski W, Haley L, Rozman R, Newell C, Sanders P, Tumer NE (1990): Engineering resistance to mixed virus infection in a commercial potato cultivar: resistance to potato virus $\mathrm{X}$ and potato virus $\mathrm{Y}$ in transgenic Russet Burbank. Nat. Biotechnol. 8, 127-134. https://doi. org/10.1038/nbt0290-127

Lee G, Shim H-K, Kwon M-H, Son S-H, Kim K-Y, Park E-Y, Lee T-K, Lee W-R, Auh C-K, Kim D, Kim Y-S, Lee S (2013a): A nucleic acid hydrolyzing recombinant antibody confers resistance to curtovirus infection in tobacco. Plant Cell Tissue Organ Cult. 115, 179-187. https://doi.org/10.1007/ s11240-013-0357-4

Lee G, Shim H-K, Kwon M-H, Son S-H, Kim K-Y, Park E-Y, Yang J-K, Lee T-K, Auh C-K, Kim D, Kim Y-S, Lee S (2013b): RNA virus accumulation is inhibited by ribonuclease activity of 3D8 scFv in transgenic Nicotiana tabacum. Plant Cell Tissue Organ Cult. 115, 189-197. https://doi. org/10.1007/s11240-013-0351-x

Lee G, Yu J, Cho S, Byun SJ, Kim DH, Lee TK, Kwon MH, Lee S (2014): A nucleic-acid hydrolyzing single chain antibody confers resistance to DNA virus infection in Hela cells and C57BL/6 mice. PLoS Pathog. 10, e1004208. https:// doi.org/10.1371/journal.ppat.1004208

Longstaff M, Brigneti G, Boccard F, Chapman S, Baulcombe D (1993): Extreme resistance to potato virus X infection in plants expressing a modified component of the putative viral replicase. EMBO J. 12, 379.

Malcuit I, de Jong W, Baulcombe DC, Shields DC, Kavanagh TA (2000): Acquisition of multiple virulence/avirulence determinants by potato virus X (PVX) has occurred through convergent evolution rather than through recombination. Virus Genes 20, 165-172. https://doi. org/10.1023/A:1008178800366

Murashige T, Skoog F (1962): A revised medium for rapid growth and bio assays with tobacco tissue cultures. Physiol. Plant. 15, 473-497. https://doi.org/10.1111/j.1399-3054.1962. tb08052.x

Nickel H, Kawchuk L, Twyman RM, Zimmermann S, Junghans H, Winter S, Fischer R, Prüfer D (2008): Plantibodymediated inhibition of the Potato leafroll virus $\mathrm{P} 1$ protein reduces virus accumulation. Virus Res. 136, 140-145. https://doi.org/10.1016/j.virusres.2008.05.001

Peretz Y, Eybishtz A, Sela I (2011): Silencing of ORFs C2 and $\mathrm{C} 4$ of tomato yellow leaf curl virus engenders resistant or tolerant plants. Open Virol J. 5, 141. https://doi. org/10.2174/1874357901105010141

Prins M, de Oliveira Resende R, Anker C, Van Schepen A, Haan P, Goldbach R (1996): Engineered RNA-mediated resistance to tomato spotted wilt virus is sequence specific. Mol. Plant-Microbe Interact. 9, 416-418. https://doi. org/10.1094/MPMI-9-0416

Prins M, Laimer M, Noris E, Schubert J, Wassenegger M, Tepfer M (2008): Strategies for antiviral resistance in transgenic plants. Mol. Plant Pathol. 9, 73-83.

Rairdan GJ, Collier SM, Sacco MA, Baldwin TT, Boettrich T, Moffett P (2008): The coiled-coil and nucleotide binding domains of the potato $\mathrm{Rx}$ disease resistance protein function in pathogen recognition and signaling. Plant Cell 20, 739-751. https://doi.org/10.1105/tpc.107.056036

Rakosy-Tican E, Aurori CM, Dijkstra C, Thieme R, Aurori A, Davey MR (2007): The usefulness of the gfp reporter gene for monitoring Agrobacterium-mediated transformation of potato dihaploid and tetraploid genotypes. Plant cell reports 26, 661-671. https://doi.org/10.1007/s00299-006-0273-8

Runo S (2011): Engineering host-derived resistance against plant parasites through RNA interference: Challenges and opportunities. Bioengineered 2, 208-213. https://doi. org/10.4161/bbug.2.4.15879

Sacco MA, Mansoor S, Moffett P (2007): A RanGAP protein physically interacts with the NB-LRR protein $\mathrm{Rx}$, and is required for Rx-mediated viral resistance. Plant J. 52, 82-93. https://doi.org/10.1111/j.1365-313X.2007.03213.X

Safarnejad MR, Fischer R, Commandeur U (2009): Recombinantantibody-mediated resistance against tomato yellow leaf curl virus in Nicotiana benthamiana. Arch. Virol. 154, 457-467. https://doi.org/10.1007/s00705-009-0330-Z

Schwach F, Vaistij FE, Jones L, Baulcombe DC (2005): An RNAdependent RNA polymerase prevents meristem invasion by potato virus $\mathrm{X}$ and is required for the activity but not the production of a systemic silencing signal. Plant Physiol. 138, 1842-1852. https://doi.org/10.1104/ pp.105.063537

Solomon-Blackburn RM, Barker H (2001a): Breeding virus resistant potatoes (Solanum tuberosum): a review of traditional and molecular approaches. Heredity $86,17-35$. https:// doi.org/10.1046/j.1365-2540.2001.00799.x

Solomon-Blackburn RM, Barker H (2001b): A review of host majorgene resistance to potato viruses $\mathrm{X}, \mathrm{Y}, \mathrm{A}$ and $\mathrm{V}$ in potato: genes, genetics and mapped locations. Heredity 86, 8-16. https://doi.org/10.1046/j.1365-2540.2001.00798.x

Sonoda S, Koiwa H, Kanda K, Kato H, Shimono M, Nishiguchi M (2000): The helper component-proteinase of Sweet potato feathery mottle virus facilitates systemic spread of Potato virus X in Ipomoea nil. Phytopathology 90, 944-950. https://doi.org/10.1094/PHYTO.2000.90.9.944

Tameling WI, Baulcombe DC (2007): Physical association of the NB-LRR resistance protein Rx with a Ran GTPaseactivating protein is required for extreme resistance to 
Potato virus X. The Plant Cell 19, 1682-1694. https://doi. org/10.1105/tpc. 107.050880

Tavladoraki P, Benvenuto E, Trinca S, De Martinis D, Cattaneo A, Galeffi P (1993): Transgenic plants expressing a functional single-chain Fv antibody are specifically protected from virus attack. Nature 366, 469-472. https:// doi.org/10.1038/366469a0

Tramontano A, Janda KD, Lerner RA (1986): Catalytic antibodies. Science 234, 1566-1570. https://doi.org/10.1126/ $\underline{\text { science. } 3787261}$ van den Boogaart T, Wen F, Davies J, Lomonossoff G (2001): Replicase-derived resistance against pea early browning virus in Nicotiana benthamiana is an unstable resistance based upon posttranscriptional gene silencing. Mol. Plant-Microbe Interact. 14, 196-203. https://doi. org/10.1094/MPMI.2001.14.2.196

Verchot-Lubicz J, Ye CM, Bamunusinghe D (2007): Molecular biology of potexviruses: recent advances. J. Gen. Virol. 88, 1643-1655. https://doi.org/10.1099/vir.0.82667-0 